\title{
Training and Improving the Quality of Human Resources in Ethnic Minority and Mountainous Areas in Vietnam in Current Context
}

\author{
Le Van Loi* \\ Department of Scientific Management, Ho Chi Minh National Academy of Politics, Hanoi, Vietnam \\ *Corresponding author: Levanloinpa@yahoo.com \\ Received February 05, 2019; Revised March 25, 2019; Accepted March 28, 2019
}

\begin{abstract}
In the development resources of each country, human resources are considered to be the most important, precious, and decisive, especially for Vietnam. The development of human resources in ethnic minority and mountainous areas is one of the important tasks for hunger eradication and poverty reduction sustainably and effectively, promoting quickly socio-economic development of the areas. Being aware of the great role and significance of the human resources, the Government of Vietnam has issued and implemented many direct and indirect policies related to training and improvement of human resources in the ethnic minority and mountainous areas and have initially achieved certain results such as: Strengthening learning opportunities for ethnic minority and mountainous students through a system of boarding and semi-boarding ethnic minority schools and school points; Improving the quality of ethnic minority human resources through vocational training; Enhancing the quality of education for ethnic minority students through nomination or priority policies for points by areas when taking entrance exams to colleges, universities, etc. However, besides the achieved results, there are still limitations and shortcomings in training and improving the quality of human resources in ethnic minority and mountainous areas in Vietnam. Therefore, it is necessary to synchronously implement solutions on training and improving the quality of human resources in ethnic minority and mountainous areas, meeting the requirements of socio-economic development of the population, ethnic groups and mountainous areas in particular and Vietnam in general in the new period.
\end{abstract}

Keywords: training, improving, quality of human resources, ethnic minority and mountainous areas, Vietnam

Cite This Article: Le Van Loi, "Training and Improving the Quality of Human Resources in Ethnic Minority and Mountainous Areas in Vietnam in Current Context." American Journal of Educational Research, vol. 7, no. 3 (2019): 284-293. doi: 10.12691/education-7-3-14.

\section{Introduction}

Human resource is the biggest asset, a decisive factor for the existence and development of the country. In recent years, the human resources and human resource development are mentioned in many different levels and aspects. In particular, many works research systematically on human resources, education and training to improve the quality of human resources and effectively use the human resources.

Improving the quality of human resources to meet the requirements of industrialization and modernization of the country by Mai Quoc Chanh analyzed the role of the human resources, the need to improve the quality of the human resources. Since then, the author proposes some basic solutions to improve the quality of the human resources in Vietnam to meet the requirements of industrialization and modernization [1]. Bui Ngoc Lan in Intellectual resources in the innovation career in Vietnam has analyzed the position, role and function of the intellectual resources and affirmed that this is a central part, making the quality and the increasing power of the human resources, are invaluable assets of every country, nation and all humanity. Thence, the author offers the solutions to promote intellectual resources of Vietnam in the national innovation and construction [2]. In Human resource development - world experience and practice in Vietnam, the authors have introduced an overview of the role of the human resources in some countries around the world under the impact of education and training, stating the role of the education and training in the human resource development in Vietnam [3]. Effectively using human resources in Vietnam by Nguyen Huu Dung has presented systematically some theoretical and practical issues related to the distribution and use of human resources in development in Vietnam. At the same time, proposing some policies and solutions to rationally distribute and effectively use the human resources in the socio-economic development in Vietnam in the current context [4].

In ethnic minority and mountainous areas of Vietnam, the ethnic minority human resources are central factors, 
playing a decisive role in socio-economic growth and development. In-depth studies on the ethnic minority human resources, policies for training, improving and developing the human resources in ethnic minority areas such as:

Young human resources of ethnic minorities by author Dang Canh Khanh has evaluated the actual situation of young human resources of ethnic minorities in terms of physical, health, learning, labor, cultural and spiritual life, lifestyle and personality. The author has also proposed the solutions to improve the quality of young human resources in ethnic minority and mountainous areas to serve the industrialization and modernization [5]. In Characteristics of ethnic minority human resources in Vietnam: Evidence collected from ethnic minority household survey in 2009 in 11 provinces, the authors have provided the documents and data reflecting the actual situation for ethnic minority human resource development in Vietnam [6]. Lo Quoc Toan in Developing the source of ethnic minority cadres in the northern mountainous provinces of Vietnam in current context has evaluated the actual situation of working of cadre and the status of the development of ethnic minority cadres in the provinces of the northern mountainous area of Vietnam, giving the directions and solutions to develop this cadre resource [7]. Improving the quality of ethnic minority human resources in the northern mountainous provinces and the Central Highlands today by $\mathrm{Vu}$ Dinh Hoe and Doan Minh Huan have surveyed and investigated the ethnic minority human resources in the North and Central Highlands, evaluated the actual situation and provided basic solutions to improve the quality of human resources in these areas [8]. In Controlling the implementation of ethnic policies in terms of education, training, improving and use, management of ethnic minority cadres in our country at present, the authors have based on objective actual material and data on the process of implementing ethnic policies in the terms of education and training and the use and management of ethnic minority cadres at present for comprehensive evaluation of achievements, inadequacies and shortcomings. Thence, the authors have made specific recommendations and requirements for local authorities at all levels in order to improve the effectiveness of ethnic policy implementation in the terms of education, training and use, management of ethnic minority cadres [9]. In Human development in the Northwest, Pham Thanh Nghi, on the basis of human development theory of some scholars and human development index of the United Nations, has evaluated the issue of human development in the Northwest, showing the advantages and disadvantages as well as the causes of limitations. Since then, the author proposes some solutions to promote the human development in the Northwest in the coming time [10]. Thao Xuan Sung in Building a team of ethnic minority civilian cadres in the innovation period has focused on evaluating the civilian cadre team and building ethnic minority civilian cadre team in the innovation period. The author has affirmed that the ethnic minority civilian cadre team plays a very important role in the civil affairs of ethnic minorities, but due to many reasons, this team is still very much shortcomings and limitations. The author proposes a number of recommendations for policy and solutions to build this team in order to meet the requirements of civil affairs of ethnic minority in the current period [11]. Nguyen Dang Thanh in Human resource development in ethnic minority areas in Vietnam to meet the requirement of promoting industrialization and modernization of the country, has shown the theoretical and practical bases of the development of ethnic minority human resources and solutions to the development of ethnic minority human resources in order to meet the requirements of promoting the industrialization and modernization of the country [12]. In conference proceedings of Human resources of ethnic minorities of Vietnam in current context and the posed issues, the scientists have articles on evaluating the overview of human resources and some suggestions for development policies of ethnic minority human resources. Many conference discussions have focused on clarifying the actual situation of ethnic minority human resources in terms of physical, stature, average life expectancy, education qualification, labor through training, labor skills, employment opportunities, political system participation, family marriage, life, income, poverty, etc.; analyzing and clarifying the causes, limitations and weaknesses of ethnic minority human resources, especially in ethnic groups with very few people, people in border areas, remote areas especially difficult; evaluating the State's policy system on ethnic minority human resource development, impact and effectiveness of the policy system to development of the quality of ethnic minority human resources in Vietnam, etc. Many discussions propose to soon complete the legal system related to ethnic minorities; build overall socioeconomic development program for ethnic minority areas and organize the specific policies on human resource training and development [13]. Vu Dinh Hoe in Identifying barriers to development of ethnic minority human resources in the northern mountainous provinces in the period of accelerating industrialization and modernization has analyzed and clarified the factors that are holding, limit the development of ethnic minority human resources in the northern mountainous provinces, including ethnic minority cadres. Thence, the author points out the requirements and solutions which need to be implemented to overcome, remove the barriers, and to meet the development of current ethnic minority human resources in the mentioned localities [14]. Ngo Thi Trinh in Improving the quality of ethnic minority human resources - strategic task of national work has analyzed and clarified the achievements in implementing human resource training and development policies and points out current limitations and inadequacies. Since then, the author proposes some solutions to improve the quality of ethnic minority human resources, including: Promoting propaganda and education to enhance awareness of community for comprehensive human resource development; Innovating education and training policies at all levels; Rapidly diversifying and developing types of vocational training and improving in ethnic minority areas; Focusing on developing human resources with the high quality; Improving the living standards in all aspects of ethnic minorities. According to the author, improving the quality of ethnic minority human resources is a strategic task, needs to focus on investment to create a solid foundation for the sustainable development of ethnic and mountainous areas [15]. In Socio-economic development 
of ethnic minority and mountainous areas in the direction of industrialization and modernization, the authors have analyzed the actual situation, difficulties and inadequacies in the process of socio-economic development in the current ethnic and mountainous areas; provided the solutions for socio-economic development in the areas mentioned in the direction of industrialization and modernization. According to the authors, the issue of low intellectual standard, low quality human resources is one of the biggest barriers to the socio-economic development of ethnic minority areas at present. Therefore, it is necessary to strengthen the education to improve the intellectual standard and training levels, especially vocational training for ethnic minority children to serve the process of industrialization and modernization in ethnic minority areas [16]. In Training and improving the quality of human resources in ethnic minority and mountainous areas - Actual situation and solutions by Pham Van Son has analyzed and clarified the actual situation, achievements and weaknesses as well as limitations of training and improving human resources in ethnic minority and mountainous areas in Vietnam in the past time. Accordingly, the author proposes some solutions to develop and improve human resources in ethnic minority and mountainous areas during the industrialization, modernization and international integration period [17]. Nguyen Quynh Hoa in Ethnic policy in Vietnam: Achievements and challenges to overcome have analyzed and clarified the content of national guidelines and policies of the State of Vietnam. According to the author, the policy of training and developing human resources still has outstanding issues at present that the quality of education and human resources in the ethnic minority and mountainous areas is low: the number of people in working age not trained accounts for a high percentage; the vocational training quality is low; medical cadres in ethnic minority and mountainous areas are both lacking and weak in their professional skills, especially ethnic minority cadres. Medical equipment is inadequate and outdated, most poor people in ethnic minority and mountainous areas do not have access to good quality health services. The grassroots political system in some places is still weak, especially the qualified cadre is limited, especially the lack of ethnic minority cadres or the ethnic cadres have not been trained yet [18]. In Some issues raised for training ethnic minority human resources in the Northwest area in current context, Nguyen Hong Hai said that the ethnic minority human resources in the Northwest area is currently large in terms of quantity but weak in terms of quality, especially the qualifications of the leaders and managers. In order to develop the Northwest area, the training of ethnic minority human resources is one of the most important and urgent tasks in order to contribute to improving the efficiency of socio-economic development and raising the intellectual standard. The author proposes three recommendations for training of ethnic minority human resources in the Northwest area: Properly resolving the relationship between the popular and the specific in the process of training ethnic minority human resources; Resolving the relationship between the training process and the use of ethnic minority human resources after training and resolving the relationship between the increase of scale, training criteria and ensuring the training quality of ethnic minority human resources [19]. Nguyen Van Ly in Improving the quality of theoretical thinking of leaders and managers at the district level of ethnic minorities in the Central Highlands (Survey of Kon Tum, Gia Lai and Dak Lak provinces) has clarified the theoretical thinking capacity of leaders and managers at the district level of ethnic minorities; analyzed the actual situation and proposed the key solutions to improve the theoretical thinking capacity of the leaders and managers at the district level of ethnic minorities in the Central Highlands at present [20].

In addition, a number of research works have presented the concept of ethnicity, ethnic area, ethnic policy and evaluated the actual situation of the implementation of ethnic policies in Vietnam in recent years. Thence, the authors provide a number of the key tasks and solutions to well implement the ethnic policies in the coming years. In particular, the issue of training and developing human resources in ethnic minority areas is mentioned from three aspects: policies, advantages and shortcomings of the policies, the actual situation of implementation of the policies and recommendations on the policy and the policy implementation in practice, typically: On the issue of ethnicity and ethnic work in our country of Committee on Ethnic Minority Affairs and Mountainous Areas [21], Basic issues of ethnic policy in our country in current context by Phan Xuan Son and Luu Van Quang [22], Building and completing the ethnic policy system in Vietnam by Le Ngoc Thang [23], Building and completing the ethnic policy system in Vietnam by Nguyen Lam Thanh [24], Improving the quality of human resources in ethnic minority and mountainous areas [25], Actual situation and quality enhancement solutions for human resources in ethnic minority and mountainous areas, [26] Enhancing the quality of human resources in ethnic minority areas with many policies [27], Education breakthroughs to develop human resources in ethnic minority and mountainous areas [28], Improving human resources in mountainous areas [29], etc.

In general, scientific works have mentioned the contents related to human resources in Vietnam in general and in ethnic minority and mountainous areas in particular, and the issues of policies for training, improving and developing human resources in ethnic minority and mountainous areas in Vietnam in the current context. Some works directly discuss the issue of training and developing human resources in ethnic minority areas, evaluate the actual situation and analyze the achievements in the implementation of human resource training and development policies in the practice, the achievements in improving the quality of training and human resource development. Some works have focused on clarifying the importance, content, training solutions, developing human resources for leadership and management as ethnic minorities. Thence, some basic solutions are proposed to contribute to innovate and complete the system of policies on training and developing human resources in ethnic minority areas to ensure the effective implementation of ethnic policies in Vietnam, promoting the great role of ethnic minority communities in the national industrialization and modernization. This article generically introduces the ethnic minority and mountainous human resources in 
Vietnam in the current context, studies the actual situation of training and improving the quality of human resources in ethnic minority and mountainous areas, causes and solutions to improve the quality of human resources in ethnic minority and mountainous areas in Vietnam in the current context.

\section{Content}

\subsection{General Overview of Human Resources in Ethnic Minority and Mountainous Areas}

The ethnic minority and mountainous areas of Vietnam are located on a geographical space spreading from the North to the South, accounting for $3 / 4$ of area of the whole country. In 63 provinces and cities nationwide, there are 54 provinces in ethnic minority and mountainous areas, including: 12 upland provinces, 9 mountainous provinces, 23 provinces with mountainous districts and communes and 10 provinces in the Mekong Delta, where there are many ethnic minority people. Currently, there are 56/63 cities, 463 districts and 5,453 communes with ethnic minority people living in communities in sub-hamlets, villages, hamlets, etc. [30]. According to the General Statistics Office of Vietnam, provinces and cities under central authority in ethnic minority and mountainous areas have a total of $68,194,369$ ethnic minority and Kinh people who are living, accounting for $79.43 \%$ of the total population of the whole country, in which the number of ethnic minority people is $12,251,436$ people, accounting for $14.27 \%$ of population of the whole country and accounting for nearly $18 \%$ of the population of provinces with ethnicity and mountainous areas [31].

The ethnic minority people live mainly in three areas with harsh natural conditions (rugged mountains, remote and secluded, suffering from many natural disasters, floods, etc.), in which ethnic minorities living in the Northern midlands and mountains area accounts for $48.6 \%$, in the North Central and Central Coast and the Central Highlands accounts for $29.3 \%$. Provinces with the highest percentage of ethnic minority people of more than $50 \%$ of the population are Cao Bang, Ha Giang, Bac Kan, Lai Chau, Dien Bien, Son La, Lang Son, Hoa Binh, Lao Cai and Yen Bai. The ethnic minority group with a population of over 1 million people is Tay, Thai, Muong, Khmer, Hmong. This is a group of ethnic groups with their own writing and a abundant cultural life and rich identity; the ethnic groups have a population of between 1,000 and under 5,000 including Lo Lo, Mang, Co Lao, Bo Y, Cong and Ngai; The ethnic minority group has a population of less than 1,000 including Si La, Pu Peo, Ro Mam, O Du, Brau.

In the terms of physical strength of human resources in ethnic minority and mountainous areas: For a ethnic minority group, the rate of malnutrition in children is still high, such as the ethnic group of Mang (40.3\%) and La $\mathrm{Hu}(44 \%)$, Co Lao (47.37\%), etc. The rate of stunting malnutrition among ethnic minority children under 24 months of age decreased from $35 \%$ (in 1998) to $33 \%$ (in 2006), The number of malnourished children at the age of 24 months and older increased from 54\% (1998) to 57\%
(2006). Mortality rates for children under 1 year of age in ethnic minority areas are high, in the Northern mountainous provinces and in the Central Highlands, the mortality rates for children is twice as high as that of Lai Chau (47.7\%), Dien Bien (39.7\%), Ha Giang (37.5\%), Kom Tum (38.2\%) [32],... Women of reproductive age under 15 years old are high and over 15 years old are low. The child marriage before 19 years of age is high: $15 \%$ for men, $36.8 \%$ for women in the Northern Midlands and Mountainous area; $10 \%$ for men and $31.8 \%$ for women in the Central Highlands [33]. Most ethnic minority households are crowded. In the Northern Midlands and Mountainous area, the average household size has 4 people, with $31.4 \%$ of households having 5 or more children; In the Central Highlands, the average household size has 4.1 people, with $35.9 \%$ of households having 5 or more children [31]. The life expectancy of ethnic minorities is also lower than the average life expectancy of the country. The level of life expectancy difference between men and women is also higher than the average level. The average life expectancy of ethnic minorities in some provinces is very low such as: Lai Chau (63.8 years), Lao Cai (65.8 years), Ha Giang (66.3 years), etc. Some ethnic groups with few people reside in difficult areas such as the Mang, La Hu, Cong, Co Lao, Pu Peo, Romam, $\mathrm{O} \mathrm{Du}$, etc. with a low average life expectancy of 50-55 years [31].

In previous years, in addition to job creation for ethnic minority people, the Government of Vietnam has many policies to eliminate illiteracy for ethnic minorities and mountainous people, because only a few people of ethnic minority and mountainous areas universalize their education levels at primary, secondary and high school levels. The number of ethnic minority people at the age of 15 and over who cannot read or write in national language is $20.8 \%$. The right enrollment rate for ethnic minority children is only $88.9 \%$. The rate of children not graduating from primary school of other ethnic groups in general, including ethnic minorities in particular, is very high, accounting for $34.2 \%$. The rate of primary graduation is $28 \%$. This rate also decreases at higher education levels such as levels of secondary and high school. The rate of secondary graduation rate is $15.2 \%$. The dropout rate of ethnic minority children after completing secondary school is 35\% and high school graduation is $9.0 \%$ [34]. Education qualification in ethnic minority and mountainous areas is low so the qualified labor force of ethnic minorities and mountainous areas is also very low, mainly from the ethnic minority labor force as unskilled workers not graduated or finished educational program of high school. The labor force with primary, intermediate, college, university and postgraduate professional qualifications of ethnic minorities and mountainous areas is very low. Most of this professional force is objects of nomination of ethnic minority people (be selected to colleges and universities, etc., then return to the localities to work in the missing positions). This is a knowledgeable labor force but has been assigned a job position before going to school. The rate of workers who graduated from primary qualification is $0.1 \%$, intermediate qualification is $2.81 \%$, college qualification is $0.75 \%$, university qualification is $1.08 \%$ and postuniversity qualification is $0.03 \%$ [34]. 
Based on age, gender and production fields, human resources in ethnic minority and mountainous areas are divided into:

Structure of human resources by age: Human resources in the whole ethnic minority and mountainous areas are $31.03 \%$ of the population aged 15 and under, including $25.38 \%$ of the population at the age of 12 to 15 years old (age at secondary school). Among 8,452,266 people at the age of 15 and older, there are 4,305,552 people at high school age (16-18 years old) accounting for nearly $10 \%$ [31]. For ethnic minority human resources, there is $25.55 \%$ of the population at the age of 15 and under, in which $28.84 \%$ of the population is between the ages of 12 and 15 (the age of attending secondary school). Among $50,769,895$ people at the age of 15 and older $(74.45 \%$ of the total population) nearly $10 \%$ of the age group 16 to 18 years old is the age of attending high school [31].

Structure of human resources by gender: The ethnic minority human resources have a gender imbalance, the rate of men is low, accounting for $42.8 \%$ and the rate of women is high, accounting for $57.2 \%$. Some ethnic groups have very high gender difference between men and women: Xtieng (16.88\%), Mnong (16.42\%), Chu Ru, Ta Oi, Lo Lo (over 16\%), Khmer (15.88\%), Raglay (15.72\%). Some ethnic groups have a higher rate of men than women such as $\mathrm{O} \mathrm{Du}$ (men account for $52.8 \%$ and women account for $41.8 \%$ ), $\mathrm{Si} \mathrm{La}$ (men account for $52.3 \%$ and women account for $47.7 \%$ ) [31],... The gender imbalance has significantly affected the quality of ethnic minority human resources at present.

Structure of human resources by production fields: Human resources in ethnic minority and mountainous areas are mainly concentrated in agricultural production, especially in 2 areas with the highest number and rate of ethnic groups in Vietnam is the Northern Midlands and Mountains and the Central Highlands with over $70 \%$ of agricultural production. Industry, service and trade fields only have a small rate of participants. In general, the workers in ethnic minority and mountainous areas mainly participate in farming and simple occupations, is less participation in the fields which require the high and medium technical expertise. "In the northern mountainous and midland areas, $78.44 \%$ of the population at the age of 15 and over are working in agriculture field and simple occupations; In the North Central and Central Coast, this rate is $64.81 \%$; in the Central Highlands, this rate is $76.33 \%$, partly reflecting the actual situation of qualifications and capacity of current ethnic and mountainous people" [26]. With ethnic minority priority policies, the management leaders in ethnic minority and mountainous areas account for $0.92 \%$ of the whole country. The provinces with the majority of ethnic minority people in the Mekong Delta have the lowest rate of leadership work, $0.56 \%$, the provinces in the Central Highlands have a rate of $0.76 \%$ and the Northern midlands and mountains account for $0.85 \%$. In the election of deputies to the National Assembly and People's Councils at all levels, the number of deputies who are ethnic minority people account for $17.7 \%$ with $87 / 493$ members of the 12th National Assembly. At the local level, the rate of ethnic minority people participating in People's Councils at all levels accounts for a large number with $20.53 \%$ at the provincial level, $20.18 \%$ at the district level and $24.4 \%$ at the commune level. The rate of people's committee members at all levels is $10.9 \%$ (provincial level), $11.32 \%$ (district level) and 17.9\% (commune level).

\subsection{Actual Situation of Training and Improving the Quality of Human Resources in Ethnic Minority and Mountainous Areas}

Having a clear awareness on the great role and significance of human resources, the Government of Vietnam has issued many policies directly related to training, improving and developing human resources in ethnic minority, mountainous areas and implements such as: Policy on building and developing boarding schools for ethnic minority students; Policies on nominating the students to enter universities, colleges and professional secondary schools to meet the requirements of cadres who are ethnic minorities in the locality; Priority policy on the points for the students going to university and college exams creates opportunities for the students in mountainous areas with difficult socio-economic conditions; Policies on supporting the students who are poor children in extremely difficult communes; Project on supporting vocational training for rural workers according to Decision No. 1956/QD-TTg; Credit policy for poor pupils and students. In addition, the Government of Vietnam also issued a number of policies that indirectly affect the development of human resources in mountainous areas, such as Program 135, Stage II; Resolution No. 30a /2008/NQ-CP of the Government on fast and sustainable poverty reduction with 62 poor districts in the period of 2009 - 2020, etc.

For many years, implementing the ethnic policies on the principle of "Equality, solidarity, respect and support each other to progress", the work of education and training, improving and enhancing the quality of human resources in the ethnic minorities and mountainous areas in Vietnam have achieved important results:

Strengthening the learning opportunities for ethnic minority and mountainous students through a system of boarding, semi-boarding schools and school points.

In the process of building and developing, implementing the priority policies to create resources, build teams of labor and knowledge who are ethnic minority people, the education and training in mountainous and ethnic minority areas has achieved certain achievements. The good implementation of the education and training work, the intellectual standard of ethnic minority and mountainous areas has been significantly improved, successfully implemented the career of illiteracy eradication and universalization of primary and secondary education and is opened to the hamlets and villages. According to the survey results on the socio-economic situation of 53 ethnic minorities of the General Statistics Office and the Committee on Ethnic Minority Affairs, as of August 1, 2015: the number of ethnic minorities at the age of 15 and over who can read and write is 7,465,062 people (reaching $79.8 \%$ ); the number of ethnic minority people at the age of 15 and over who can read and write the national language is 7,416,732 people (reaching 79.2\%); the rate of employed people trained at the age of 15 and over reaches 
$6.2 \% ; 70.2 \%$ of students at the right age to go to school and the right level; The total number of schools in ethnic minority communes is 17,722 [35].

The system of ethnic minority boarding and semi-boarding schools is established, the ethnic minority students at education levels increases rapidly; many school models and system of boarding ethnic minority schools have been continuously strengthened and developed such as: ethnic youth school, school of taking classes while working, ethnic boarding and semi-boarding high school, preparatory school for ethnic minorities to train ethnic minority cadres. If the school year 1997 - 1998, the ethnic minority boarding high school was only available in 39 provinces with 211 schools and nearly 50,000 students; In the school year2008-2009, there were 285 ethnic minority boarding high schools, including: 7 central schools, 47 provincial schools, 231 district and commune schools with about 85,000 students. In 2014, there were 11 central schools attracting more than 5,000 students each year, the provincial level has about 48 schools attracting more than 20,000 students each year and the district has 268 schools attracting more than 60,000 students to attend [36]. In the school year 2014-2015, "there were 304 ethnic minority boarding high schools with nearly 64,697 students of 45/53 ethnic minorities, including 215 district schools and 89 provincial schools. In the school year 2014 - 2015, the number of primary school students being ethnic minority children is 1,316,048; secondary school has 816,995 children; high school has 296,868 children" [37]. The programs of teaching ethnic languages for boarding ethnic minority students are interested, and many textbooks for ethnic minority people are compiled as the writing of ethnic groups of Khmer, Hmong, Mnong, Ban, Ede, Cham, etc. Many provinces have implemented programs to teach bilingual and ethnic minority languages in schools such as Soc Trang, Hau Giang, Bac Lieu, Vinh Long, Dak Lak, Gia Lai, Yen Bai and Lao Cai, etc.

Improving the quality of human resources in ethnic minority and mountainous through vocational training.

The system of universities, colleges, professional secondary and vocational schools continues to be strengthened and developed; The level of skill and technical expertise of the labor force is gradually raised; The potential of science and technology has achieved significant development. In particular, the Government of Vietnam pays special attention to vocational training for ethnic minorities and mountainous people. Currently, in Vietnam there are about 1 million poor households who are ethnic minorities, in which more than 400,000 households have no land and lack of productive land, so the poverty reduction must be by vocational training [38]. Therefore, the Prime Minister has issued a project to support vocational training for rural workers in accordance with Decision No.1956/QD-TTg with the main content of vocational training for rural, ethnic minorities and mountainous workers, implemented to overcome the shortage of productive land, as well as the transformation of labor structure. In addition, according to Circular No. 58/2017/TT-BTC on guiding a number of financial support policies for organizations and employers who are ethnic minorities in mountainous areas, especially difficult areas under poor ethnic minority households, the maximum support level is VND 4 million/person/course; ethnic minority people receive the maximum support level up to VND 3 million/person/course. At the same time, supporting for meals is VND 30,000/person/day for study. Supporting for travel is VND 200,000/person/course if the training site is $15 \mathrm{~km}$ or more away from the residence. This regulation aims to motivate ethnic minority people to go to vocational training [39]. The results of vocational training for rural workers in ethnic minority areas have achieved results: The total number of ethnic minority workers who attend the vocational training is 223,792 , accounting for $25.24 \%$ of the total number of trained workers. The rate of ethnic minority workers in the age of vocational training according to the Project $1956 /$ QD-TTg is $223,792 / 7,820,909$ people, accounting for $2.86 \%$ (while the rate of trained workers in the age of the country is $37.3 \%$ ). The rate of ethnic minority self employed workers after vocational training accounts for $63.1 \%$; especially, the rate of self - employed agricultural workers is very high $(87.74 \%)$. The results of vocational training for less than one year in 32 provinces only account for $4.97 \%(938,930 / 18,874,910)$ compared to the workers in the age group. The results of vocational training for less than one year in 26 provinces with a large number of ethnic minority people account for only $5.73 \%$ $(277,659 / 4,850,247$ people). The results of vocational training at the intermediate level in 21 provinces with a large number of ethnic minorities account for only $0.48 \%$ of the total number of ethnic minority workers $(18,641 / 3,887,043$ people). The results of vocational training at the college level of 16 provinces with a large number of ethnic minority people account for only $0.17 \%$ of the total number of ethnic minority workers $(6,016 /$ $3,445,927$ people). From 2010 to 2013 , there were 16,000 ethnic minority workers benefiting from the labor export policy, went to work abroad for a certain period of time, in which 7,132 ethnic minority workers were in 62 poor districts. The majority of ethnic minority and mountainous workers joining in the labor export have stable jobs and income. The number of high-income workers sent money to the family. Many households with this income source have escaped the poverty, invested in housing construction, property procurement, investment in production and business development effectively. Therefore, the overall poor household rate of the whole country decreases quite high, from $14.27 \%$ in 2010 to $9.6 \%$ in 2012 (down $4.67 \%$ ). The regional poor household rate decreases from $4.24 \%$ to $7.91 \%$. The rate of near-poor households in the country has decreased very little, from $7.51 \%$ in 2010 to $6.57 \%$ in $2012(0.94 \%)$. The rate of poor households in the provinces with a large numbers of ethnic minority people in the four areas is much higher than the national poor household rate: $35.03 \%$ in Ha Giang; $45.38 \%$ in Dien Bien; 39.49\% in Quang Binh; 40.21\% in Quang Tri; $27.95 \%$ in Dak Lak; $38.58 \%$ in Dak Nong; $28.24 \%$ in Soc Trang and 29.14\% in Tra Vinh [40].

Improving the quality of education for ethnic minority and mountainous students through nomination policy or priority policy on points under areas when enrolling in colleges and universities.

The system of preparatory schools is developed both in terms of training scale and facilities. The mountainous area has 4 regional university centers: Northwest, Northeast, Central Highlands and Southwest. The regime 
of nominating the ethnic minority and mountainous students to universities, colleges, professional secondary schools has been implemented and achieved the results. Nomination criteria for ethnic minority and mountainous students in intermediate schools, colleges and universities are increasing, with an average of more than 30,000 ethnic minority and mountainous students each year studying according to this regime. The objects of the nomination program after graduation will be assigned to work without implementing the test of civil servants and public employees. Currently, the ethnic minority people have more than 13,000 people with qualification of postgraduate, universities and colleges, more than 78,000 people with professional secondary qualification, technical workers have more than 60,000 people [41].

However, in addition to the achieved results, the work of education and training, improving and enhancing the quality of human resources in ethnic minority and mountainous areas also reveals limitations and shortcomings such as:

Universalization of primary education and illiteracy eradication for ethnic minorities and mountainous areas has not yet reached the set criteria. Up to now, the rate of illiteracy and reilliteracy population of ethnic minorities is still high, the highest rate of dropouts is students in highland, remote areas, female students and children of poor families. Every year, there are still about 3.6\% of ethnic minority students of non-school age, the rate of dropouts is still high compared to other areas in the country, in which the Northwestern mountainous area is $6.9 \%$, the Central Highlands is $17.16 \%$, the Mekong Delta is $12.64 \%$. In highland areas, the number of illiterate girls in the 10 -year-old group is $13.69 \%$, from 11 to 14 years is $7.98 \%$, and from 15 to 17 years is $9.08 \%$. In particular, for ethnic groups, the girl of the Hmong is $90 \%$, Ha Nhi is $89 \%$, Gia Lai is $83 \%, \mathrm{Ba} \mathrm{Na}$ is $82 \%$ [42]. Some ethnic minorities do not yet have students graduating from high school. The number of people at the age of 15 and over in some ethnic minorities who do not know how to read and write is still relatively high such as: Tay $(5.1 \%)$, Muong (5.5\%), Thai (18.1\%), Khmer (24.4\%), Hmong (54\%), etc. Up to now, the number of ethnic minority people who do not have technical or trained qualifications account for $95 \%$ of workers in the age group. Some ethnic groups have a high rate of unskilled worker ages such as Mong (98.7\%), Khmer (97.7\%), Thai (94.6\%), Muong (93.3\%) [26], etc. The qualification of leaders and managers in ethnic minority areas is still low, failing to meet the requirements of socio-economic development of localities: "The rate of ethnic minority cadre in the provincial and district People's Committees are still low (about 11.32). In the total of 48,200 ethnic minority cadres at the commune level, the number of people with secondary education accounts for $45.7 \%, 18.7 \%$ of primary schools, only $1.9 \%$ of college and university qualifications. The cadres of villages, hamlets, sub-hamlets have low capacity and qualifications. Besides, the trained working age force of ethnic minority and mountainous areas is $10.5 \%$ " [37]. Therefore, the human resources of ethnic minority and mountainous areas with university and postgraduate qualifications only reach $2.8 \%$, in which ethnic minority people account for $1.1 \%$ and is 4 times lower than the whole country [37].
In addition, the semi-boarding school model is an outstanding model in extremely difficult areas but the development of the boarding ethnic minority school network and scale is not uniform among localities, the facilities in standard schools are seriously lacking and degraded, many construction items of many boarding schools due to construction have been degraded for a long time, many temporary construction items, not qualified according to regulations, such as: $82.81 \%$ of schools do not have beds, $92.19 \%$ of schools do not have toilets, bathrooms, $84.38 \%$ of schools do not have clean water sources [42]. In order to strengthen and develop the system of boarding ethnic minority high schools, the Prime Minister issued Decision No. 1640/QD-TTg dated September 21, 2011 on approving investment in building 48 new ethnic minority high schools in the period of 2010-2015, but the results are not achieved as planned. In the period of 2010 - 2015, only 10 schools have been completed, and 22 schools are in progress and 16 schools have not been invested in new construction and forced to be implemented in the period of 2016 - 2020 [43].

The policy of nomination, priority on points to ethnic minority students when taking entrance exams into colleges and universities also reveals many shortcomings and inadequacies. The situation of a part of the nominated students has broken the commitment to find jobs in the city and there are localities sending the students to the university to enroll, but when the students return, they do not accept to assign the jobs. The use and arrangement of the jobs for ethnic minority pupils and students after graduation is still embarrassing and passive, have many shortcomings and have not caught up with the development of the economy. The arrangement and use in cases are not appropriate with the qualifications and capacity of trained pupils and students. In the total of 4,517 student of nomination graduation, only 1,663 jobs are arranged (only 36.15\%). The demand for enrolling nomination students in the localities is also on a downward trend. In 2017 , there were only 8 provinces with a demand of nomination students with a small number of 78 university criteria and no province has demand for nomination students at college and intermediate qualifications [43].

The limitations and inadequacies in the training and improving the quality of human resources in ethnic minority and mountainous areas in Vietnam have many causes:

The poverty makes children not fully cared for at an early age, making people in ethnic minority and mountainous areas lacking the nutrients, have weak health and easily infected due to poor resistance. Although Vietnam has got the achievements in poverty reduction among ethnic minority groups in recent years, about $50 \%$ of population of the ethnic minority groups still live in the poverty line [44]. The rate of children being low, underweight and the malnutrition of children in ethnic minority and mountainous areas decreases every year but are still high compared to the national average. At present, communes of ethnic minority and mountainous areas have commune medical stations, but people in ethnic minority and mountainous areas, especially in mountainous areas, have little access to services of health care. The quality of health care services at these medical stations is also 
limited although the Government has made efforts to strengthen the quality of health care services for people here such as: supporting doctors to work at Commune medical stations, promulgating the policies to attract medical staff in the delta to mountainous areas to work, policies to nominate the local students to attend colleges and universities, etc. Besides, the ethnic minorities and mountainous people still maintain treatment, give birth at home according to traditional customs, do not use modern medical treatment and health care services. Approximately $40 \%$ of ethnic minority people in the northern mountainous areas and $20 \%$ of the people in the Central Highlands provinces self-treat and do not go to medical facilities [31]. The situation of children marriage and consanguineous marriage is high in some ethnic minority groups. Marriage rate before 19 years is still high: $15 \%$ for men, $36.8 \%$ for women in the Northern midlands and mountainous areas; $10 \%$ for men, $31.8 \%$ for women in the Central Highlands [33], etc. These are some reasons affecting the development of physical, intellect, etc. of human resources in ethnic minority and mountainous areas.

The mountainous area is an economic structure of agriculture - forestry - industry but the agricultural field does not have a clear change between cultivation, husbandry and processing; Commodity production has not yet developed, the rate of people living in self-sufficiency is high. Infrastructure of ethnic minority and mountainous areas has not met the development requirements. Labor structure has slow restructuring, affecting the socio-economic development in general and human resource development. The socio-economic development programs have not been closely integrated, so the effectiveness is not high, especially the programs on culture, education and training, and population related to human resource development.

The education system is lacking in both quantity and quality of teachers and teaching methods. The curriculum is not really suitable for many groups of learners of each ethnic minority area. The management of training, improving and development of mountainous human resources has not been paid attention suitably. The system of vocational training facilities for ethnic minorities and mountainous people still has many shortcomings. Investment resources for vocational training from the state budget are not satisfactory, vocational training equipment is inadequate, a number of vocational managers have not had practical experience.

Career guidance for ethnic minority students and people is still limited and streaming the students after graduating from secondary and high schools faces many difficulties. A part of people is not aware of the importance of education, training and vocational training, psychology of families of the students does not want their children to be joined in vocational training or professional secondary school.

Developing human resources with high quality is the main goal set out in Socio-Economic Development Strategy of the Government, however, currently, the rate of untrained ethnic minority workers in mountainous areas is still very high because the short-term and long-term vocational training courses are not appropriate and cannot meet the demands of ethnic minority workers. Programs and contents of vocational training are slowly reformed to keep up with the requirements of the labor market. Training facilities have not actively linked the training facilities with job creation, not combined with enterprises to create jobs for the students attending the vocational training after graduation.

\subsection{Solutions for Education and Training to Improve the Quality of Human Resources in Ethnic and Mountainous Minority}

It is extremely important and urgent to develop human resources in Vietnamese ethnic and mountainous minority in the current period, its purpose is to speed up the socio-economic development of ethnic and mountainous minority, to increase income, and to improve the material and spiritual life for the people here in a sustainable way. To improve the quality of human resources in ethnic and mountainous minority, it is necessary to synchronously perform many tasks, especially in education and training: Post-graduate, university, college and intermediate training. professional, illiterate eradication, short-term vocational training, elementary level vocational training, non-agricultural vocational training and intermediate vocational training, training and fostering to improve knowledge and management capacity for commune staff achieving the standards as regulated, ... In solutions to improve the quality of human resources in ethnic and mountainous minority, the solution on education and training has an important role and a decisive meaning.

Firstly, building and supplementing education and training policies at appropriate levels to improve the quality of human resources in ethnic and mountainous minority such as policies on enrollment and training, policies on children of ethnic minority areas at universities, colleges, professional secondary schools and post-training use; Support policy is suitable for students who are ethnic minority students according to each educational level, giving priority to special difficulty areas; Policies on remuneration, development, transfer of teaching staff at all levels and preferential regimes for staff working in departments and education standing committee in the ethnic and mountainous minority.

Secondly, continuing to invest in building and strengthen infrastructure, school equipment for education system from preschool to university; developing the system of schools, classrooms and educational institutions, especially building inter-boarding-school and semiboarding schools, as well as expanding professional and vocational schools connecting closely to human resources development plan and labor demand in the ethnic and mountainous minority.

Thirdly, implementing programs, contents and teaching methods in accordance with the learning conditions of ethnic minority students. Training and foresting to improve the qualifications for the ethnic and mountainous minority students before studying the majors of higher education. To meet local socio-economic development needs, which is essential to improve the efficiency of quality human resources for the ethnic minority areas. Moreover, it is necessary to well organize educational forms in order to preserve and promote national-cultural identity. 
Fourthly, diversifying and quickly developing types of training as well as foresting and developing the vocational training in the ethnic and mountainous minority. Career-oriented education is suitable to the level and capacity of each group of students. In addition, it is also necessary to include vocational training programs in the ethnic boarding schools. Consolidating the training and vocational training institutions and then assessing the situation of vocational schools for the ethnic minority students so as to adjust training contents and programs in the direction of linking with practical production and technological progress. Developing the training and vocational training plans in line with the use needs of agencies, organizations or production establishments in the region and in accordance with local socio-economic development requirements. Promoting vocational training activities, developing the vocational training network in ethnic minority and mountainous areas to improve the quality of human resources, especially youth.

Fifthly, developing the all-level teachers and building the vocational training schools' a contingent of qualified teachers in the ethnic and mountainous minority. Paying attention to the lives of teachers and managers in the ethnic and mountainous minority.

Sixthly, increasing the proportion of budget for education in ethnic minority and mountainous areas. Effectively using the national fund and programs and projects of the Government in training, using and creating jobs in accordance with the reality of each locality.

Finally, expanding international cooperation and learning experiences on training and improving the quality of human resources in the ethnic and mountainous minority. Strengthening exchanges, study and experience exchange between training institutions, establishments using labor and human resources.

\section{Conclusion}

High quality human resources play a particularly important role in the socio-economic development in the ethnic and mountainous minority in Vietnam today. It is a long process to develop the human resources for the ethnic and mountainous minority. Over the past years, the Government of Vietnam has actively invested and issued many direct and indirect policies, synchronously implemented solutions to improve the quality of human resources in the ethnic and mountainous minority, especially the innovative solutions are issued to improve the quality of education and training and enhance the quality of human resources in the ethnic minority areas. The quality of human resources in the ethnic and mountainous minority has been heightened, which really attracts and encourages many intellectuals and talented people wanting to stick to the ethnic minority areas for a long time, as well as improving the intellectuals, contributing to sustainable poverty reduction and developing the socio-economic in the ethnic and mountainous minority. However, in addition to the achieved results, the education and training works to improve the quality of human resources in ethnic minority areas has revealed many limitations such as: Results of education universalization and illiteracy eradication are not yet, the number of ethnic and mountainous minority people with professional and technical qualifications is still low, and there are still many limitations in training models at different levels ... Therefore, it is extremely necessary to synchronously implement solutions on training and fostering in order to improve the quality of human resources in the ethnic and mountainous minority in Vietnam today.

\section{References}

[1] Mai Quoc Chanh (chief editor), 1999, Improving the quality of human resources in order to meet the industrialization and modernization requirements of the country, National Political Publishing House, Hanoi.

[2] Bui Ngoc Lan, 2002, Intellectual resource for innovation in Vietnam, National Political Publishing House, Hanoi.

[3] Tran Van Tung, Le Ai Lam, 1996, Human resource development world experience and practice in Vietnam, National Political Publishing House, Hanoi.

[4] Nguyen Huu Dung, 2003, Effective use of human resources in Vietnam, Labor-Social Publishing House, Hanoi.

[5] Dang Canh Khanh, 2005, Young Human Resource of Ethnic Minorities, Youth Publishing House, Hanoi.

[6] Nguyen Dang Thanh (chief editor), 2010, Characteristics of ethnic minority human resources in Vietnam: Evidence from 2009 ethnic minority household survey in 11 provinces, Labor Publishing House society, Hanoi.

[7] Lo Quoc Toan, 2010, Developing ethnic minority cadres in northern mountainous provinces in our current country, National Political Publishing House, Hanoi.

[8] Vu Dinh Hoe, Doan Minh Huan, 2009, Improving the quality of ethnic minority human resources in the Northern mountainous provinces and the Central Highlands today, National Political Publishing House, Hanoi.

[9] Ethnic Council of the National Assembly, 2010, Monitoring the implementation of ethnic policies in the field of education, training, fosteration and use, management of the ethnic minority cadres in our current country, Publishing House National politics, Hanoi.

[10] Pham Thanh Nghi, 2010, Northwest Human Development, National Political Publishing House, Hanoi.

[11] Thao Xuan Sung, 2016, Building the ethnic minority public relations cadres during the new period, National Political Publishing House - Truth, Hanoi.

[12] Nguyen Dang Thanh, 2012, Human resource development in the ethnic minority areas in Vietnam meets the requirement to promote industrialization and modernization of the country, National Political Publishing House, Hanoi.

[13] Ethnic Council of the National Assembly, 2019, Ethnic Minority Committee, Embassy of Ireland in Vietnam, Human resources of Vietnamese ethnic minorities today and issues raised, Workshop Proceedings, Dak Lak, July 19, 2019.

[14] Vu Dinh Hoe, 2007, Identifying barriers to the development of ethnic minority human resources in the northern mountainous provinces in the period of speeding up industrialization and modernization, State Management Magazine, No.11/ 2007, 20-25.

[15] Ngo Thi Trinh, 2014, Improving the quality of ethnic minority human resources - the strategic task of ethnic work, Ethnic Journal, No. 163, 7/2014, 25-30.

[16] Le Du Phong, Hoang Van Hoa (Chief Editor), 1998, Socioeconomic development of ethnic and mountainous minority towards industrialization and modernization, National Political Publishing House, Hanoi.

[17] http://hvdt.edu.vn/AIAdmin/News/View/tabid/66/newsid/6075/seo /Dao-tao-boi-duong-nang-cao-chat-luong-nguon-nhan-luc vietnam-to-the-island.

[18] http://www.tapchicongsan.org.vn/Home/NghiencuuTraodoi/2017/45526/Chinh-sach-dan-toc-tai-Viet-Nam-Thanhtuu-va-thach-thuc.aspx.

[19] http://tcnn.vn/Plus.aspx/en/News/125/0/1010067/0/39485/Mot_so _van_de_dat_ra_doi_voi_dao_tao_nguon_nhan_luc_dan_toc_thie u_so_o_vung_Tay_Bac_hien_nay. 
[20] Nguyen Van Ly, 2015, Improving the quality of theoretical thinking of the district management leaders of ethnic minorities in the Central Highlands (Survey of Kon Tum, Gia Lai, Dak Lak), National Political Publishing House, Hanoi.

[21] Committee for Ethnic Minorities and Mountainous Areas, 2001, On the issue of ethnicity and ethnic work in our country, National Political Publishing House, Hanoi.

[22] Phan Xuan Son - Luu Van Quang (Chief Editor), 2005, Basic issues of national policy in our current country, Political Theory Publishing House, Hanoi.

[23] Le Ngoc Thang (Chief Editor), 2011, Building and perfecting the Ethnic policy system in Vietnam, National Political Publishing House, Hanoi.

[24] Nguyen Lam Thanh (Chief Editor), 2011, Building and perfecting the Ethnic policy system in Vietnam, National Political Publishing House, Hanoi.

[25] http://nhandan.org.vn/xahoi/tin-tuc/item/24707302-chong-thuathay-thieu-tho.html.

[26] http://tapchidantoc.ubdt.gov.vn/2013-03 12/5e0099804edb7901a95de9addb9ab336-cema.htm

[27] https://dantocmiennui.vn/chinh-sach/tang-chat-luong-nhan-lucvung-dan-toc-thieu-so-bang-nhieu-chinh-sach/192934.html

[28] https://www.baotintuc.vn/giao-duc/dot-pha-giao-duc-de-phattrien-nguon-nhan-luc-dan-toc-mien-nui-20120920073448664.htm.

[29] http://www.baophuyen.com.vn/141/141444/nang-cao-nguonnhan-luc-vung-mien-nui.html.

[30] https://www.baotintuc.vn/dan-toc-mien-nui/nhung-van-de-dat-ratu-thuc-trang-nguon-nhan-luc-cac-dan-toc-thieu-so $20180719135428670 . \mathrm{htm}$.

[31] General Statistics Office of Vietnam, 2010, The 2009 Vietnam Population and Housing census, Hanoi.

[32] Tran Thi Hanh, 2010, Research on the situation of ethnic minority human resources and proposing solutions to develop human resources in the ethnic and mountainous areas, Social Science Publishing House, Hanoi.
[33] Ministry of Culture, 2010, Sports and Tourism, Report on the results of implementation of Vietnam's family building strategy in the period 2005 - 2010, Hanoi

[34] http://www.tapchicongthuong.vn/bai-viet/nghien-cuu-danh-giathuc-trang-lao-dong-viec-lam-cua-nguoi-dan-toc-thieu-so$48897 . \mathrm{htm}$

[35] http://tapchimattran.vn/dai-doan-ket/thuc-trang-va-giai-phapcong-tac-phat-trien-giao-duc-o-vung-dan-toc-thieu-so-hien-nay14616.html.

[36] Tran Quang Tuan, 2014, Increasing investment in educational development in the ethnic minority area, State management journal, No. 223, 8/2014, 52-56.

[37] Ministry of Education and Training, 2015, Education and Training Statistics for the 2014-2015 school year, Hanoi.

[38] https://www.baotintuc.vn/dan-toc-mien-nui/dao-tao-nghe-cho-laodong-dan-toc-thieu-so-con-nhieu-bat-cap20131019094234148 .htm.

[39] http://daidoanket.vn/dan-toc/dao-tao-nghe-cho-lao-dong-dan-tocthieu-so-tao-dong-luc-de-nguoi-dan-tu-chu -tintuc377551.

[40] http://noichinh.vn/nghien-cuu-trao-doi/201312/ket-qua-thuc-hienchinh-sach-dao-tao-nghe-cho-lao-dong-nong-thon-vung-dan-tocthieu-so-tu-nam-2010-den-2013-293226/.

[41] http://tapchidantoc.ubdt.gov.vn/2014-1125/0246cc004654a63996dafed47b216718-cema.htm.

[42] To Duy Hop, Pham Duc Nghiem, 2010, Renovating the policies on education, improving people's intellectual standards and developing human resources in particularly difficult areas to reduce poverty, Communist Journal, basis major No.48, 12/2010, $25-28$.

[43] http://www.bienphong.com.vn/ton-tai-nhieu-bat-cap-trong-thuchien-chinh-sach-phap-luat-ho-tro-phat-trien-giao-duc-vung-dantoc-thieu-so-mien-nui /

[44] General Statistics Office of Vietnam, 2010, Report of Vietnam Household Living Standards Survey, Hanoi.

C) The Author(s) 2019. This article is an open access article distributed under the terms and conditions of the Creative Commons Attribution (CC BY) license (http://creativecommons.org/licenses/by/4.0/). 